\title{
IMPROVING THE SUSTAINABLE INFRASTRUCTURE DEVELOPMENT THROUGH INNOVATIVE APPROACHES IN TECHNOLOGY, MANAGEMENT AND FINANCIAL ASPECTS
}

\author{
Bambang Susantono, Abdur Rohim Boy Berawi \\ Center for Sustainable Infrastructure Development, Faculty of Engineering, Universitas Indonesia 16424, \\ Indonesia
}

Infrastructure covers various sectors that represent a large share of an economy and become a critical index of economic vitality. Both components of infrastructure: physical and social infrastructures are required to provide the necessary services for public interest. Reliable public utilities (e.g. power, telecommunication, water and gas supply, and other utilities), public works (e.g. roads, dams and canals, tunnels) and public transport (urban transport systems, railways, ports and waterways, and airports) are basic elements of a productive economy. Therefore, provision and maintenance of adequate infrastructure is essential for achieving rapid and sustainable economic growth. The adequacy of infrastructure helps to determine the country's key success factors in increasing productivity, expanding trade and industry, coping with population growth, reducing poverty, improving environmental sustainability and living standards of the society.

As massive investment is required, infrastructure development cannot be the responsibility of the public sector alone. Encouraging the participation of private sector investments is essential to maintain a sustainable infrastructure development. The publicprivate partnership will leverage a significant increase in additional finance, improve the project commercial viability and enhance the performance of the existing capital budget. Meanwhile, better management in the private sector can lead to an increased gain in project efficiency, leverage the capacity to innovate, as well as stimulate knowledge and technology transfer, which in turn will result in better quality and lower cost services.

This season, we are pleased to present ten selected papers dedicated to improving sustainable infrastructure development by addressed innovative approaches in technology, management and financial aspects. This issue is aimed towards enchancing the quality, reliability, sustainability and resilient infrastructure that will create a greater benefit for society.

The first paper, written by C. Woroniuk, P. T. Aditjandra, proposes a rail capacity framework for rail freight services in Indonesia. To develop the model, the authors use a combination of analytical and simulation approaches. The first approach is used to examine total capacity of the network and bottlenecks in the system where the infrastructure is under pressure, then the second approach is implemented to validate the results and to provide a more detailed replication of operations. The authors argue that the method is beneficial not only to analyze the capacity in the existing network, but also to identify the potential rail developments in a new area.

. The second paper, written by, E. C. Mpakati-Gama and T. Mkandawire, discusses about how urban residents respond to water shortages in three major cities of Malawi. They found evidence that residents use several mechanisms to cope with water supply interruptions and shortages, including purchasing of water from water kiosks, private homes and drawing water from unprotected sources such as wells and rivers. Unfortunately, some of the coping mechanisms may have short and long term health implications. The authors, therefore, 
suggest an urgent need to address water supply systems particularly in urban areas of Malawi to prevent people from impoverishment and water borne diseases.

The third paper, written by D. G. Carmichael and C.G. Edmonson, discusses the application of stream and royalty financing, and how both of the methods are used to assess the risks associated with financial aspects. For this purpose, a case study is undertaken, and the economic and financial analyses of each particular financing alternative are investigated. The findings show the likelihood of cash flows for typical streaming and royalty agreements, and the financial risks for parties involved in the project. These results give an insight on how the allocation of risk should be shared between parties, and what needs to be done to mitigate the financial risks or to optimize the risk allocation.

The fourth paper, written by S. Dikun, F. Lamari, A. D. Rarasati, H. Z. Rahman, D. Anggraeni, discusses the possibility of a Shariah-compliant scheme to finance infrastructure development in Indonesia. A port project development with 5-year investment plan therefore is taken on board and the application of Shariah-compliance in narrowing the financing gap during the lifetime of project was investigated. The findings show that this financial scheme has the potential to be deployed for Indonesia infrastructure development. The authors also urge the need for improvement in the investment process as well as policies and procedure modification to ensure the success of Shariah-compliant implementation.

The fifth paper, written by R. Jimoh, L. Emmanuel and B. Paul, evaluates PublicPrivate Partnership (PPP) for housing provisions in Nigeria. A set of questionnaire surveys were distributed to the occupants of 5 housing estates in two cities, followed by interviews with the agencies responsible for the estates. The findings showed that only $5.8 \%$ of the occupants (respondents) were low income earners that benefited from the 5 housing estates selected and only $38.4 \%$ of the respondents were satisfied with quality of work done by the developers. The authors argue that these particular problems are mainly caused due to the bureaucratic bottleneck and lack of access to land and housing finance by low income groups. In this case, government effort is required in creating a condusive environment that contributes to the success of housing provision, such as removing the bureaucratic impediments, setting up a monitoring committee to supervise any on-going project and opening financial access.

The sixth paper, written by G. Atmo, C. Duffield and D. Wilson, discusses the strategies to attain value for money from PPPs in power plant projects in Indonesia. The paper presents the analysis of a Delphi study based on an expert opinion survey and analyses of data from international seminars of PPP's in power projects. The findings suggest various strategies to attain VfM including government support (centralization of business permit applications, grants allocation for managing high risk projects, fuel supply arrangements, and project equity contributions), plus financial arrangements and appropriate risk allocation between the public and private sector.

The seventh paper, written by P. Leviäkangas and A. Aapaoja, discusses the concept of resilience and how resilience can be applied to transport infrastructure systems. As the first step, the authors distinguish the attributes and sub-attributes of resilience to build the resilience model. A similiar approach is also implemented for the transport infrastructure by dividing the system into several interconnected subsystems. Then the resilience model and transport system components are merged into a single system resilience matrix. The use of such matrix is argued may help the local authorities in developing a better resilience strategy.

The eighth paper, written by H. Z. Rahman, M. A. Berawi, S. I. Susilowati, P. Miraj, and J. S. Petroceany, examines the risk and the mitigation method in the Soekarno-Hatta 
International Airport Rail Link (SHIARL) project based on value engineering assessment. A set of questionnaires and focus group discussion were conducted with the stakeholders of railway infrastructure sector, including state-owned enterprises, private companies, investors, ministries, and academics. The findings showed that failure in route selection, failure in achieving the project objective, failure in construction design, failure in technology selection and potential geological problems were the highest potential risks that could affect the SHIARL project. The technology selection and a detail design of structure, therefore, were suggested by the authors in order to mitigate these potential risks.

The ninth paper, written by B. Susantono, M. A. Berawi, P. Miraj and J. S. Petroceany, discusses a scenario of transport infrastructure development to support the logistics and supply chains in Greater Jakarta, Indonesia. An extensive data collection effort was compared with logistics data, infrastructure capacity and predicted demand. The data were analyzed and findings were elaborated with the government strategy in transport development. Based on the analysis, the authors argue for the need to develop new transport infrastructures that can improve logistics development efficiently and fulfill the growing demand.

The last paper, written by W. Weningtyas, Q. Aulia, L. H. Adriani and A. Nurlayla, discusses bike lane implementation in the City of Bandung, Indonesia. The authors find that only 42 out of 151 artery and collector roads met the requirements or standards for a bike lane facility. The limitation of land and the growing traffic from motor vehicles were identified as obstacles that impede the bike lane development. Therefore, the authors suggest a more humanly method to encourage cycling activities, such as more promotion of bicycling and bike sharing, as well as a green transport campaign.

We would like to compliment to all the reviewers and editors whose cooperation and hard work made this journal possible. We hope that this special edition of CSID conveys some new insight and knowledge in the way we conduct our research. We are also pleased to accept and respond to any comment and enquiry you may have on the direction and content of CSID. We invite you to join in this venture by sending your work for consideration.

With warmest regards from the editorial desk,

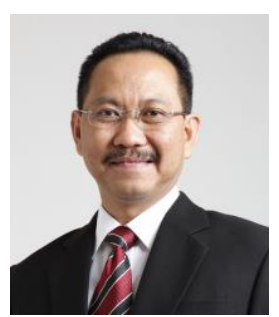

Ir. Bambang Susantono, MCP, MSCE, Ph.D Editor in Chief

CSID Journal of Infrastructure Development

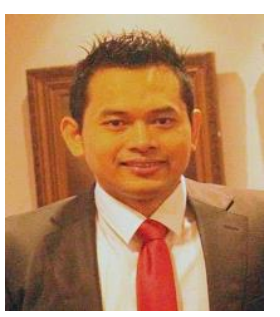

Dr. Ing Abdur Rohim Boy Berawi, MSc. Managing Editor

CSID Journal of infrastructure Development 